\title{
The Crimean Tatar Muslim Community: Between Annexed Crimea and Mainland Ukraine
}

\author{
Konrad Zasztowt (iD) https://orcid.org/0000-0003-3789-627X \\ Department for European Islam Studies \\ University of Warsaw \\ k.zasztowt@uw.edu.pl
}

\begin{abstract}
The aim of this article is the description of the religious, cultural, social, and political situation of the Crimean Tatar Muslims both living in Crimea and outside of the Russia-annexed territory of Crimea in mainland Ukraine. ${ }^{1}$ The Crimean Tatar Muslims in mainland Ukraine may be divided into two categories, those who lived there before Russia's annexation of Crimea in 2014, and those who settled there after - internally displaced persons from Crimea. In the case of the latter, one significant reason behind their migrations is persecution against them on religious grounds. Members of the Islamic communities related to the Salafi version of Islam as well as followers of Hizb utTahrir either fled from the annexed peninsula or were harshly repressed by Russian law enforcement authorities. The mainstream group of the Crimean Tatar Muslims are adherents of Sunni Islam and Hanafi Madhab. The latter is also the main Islamic religious community in Russia, which is recognized as a legitimate form of Islam by the Russian government. However, the Hanafi Crimean Muslims are also being pressured by the authorities in occupied Crimea. The leader of their religious organisation, the Crimean Muftiat, Mufti Emirali Ablayev had to declare his loyalty to the Russian state.
\end{abstract}

Keywords: Crimean Tatar Muslims, Crimean Islam, traditional Islam, Salafi Islam, religious persecution, muftiat, ethno-Islamic policy

Słowa kluczowe: krymskotatarscy muzułmanie, islam krymski, islam tradycyjny, islam salaficki, prześladowania religijne, muftiat, polityka etno-islamska

${ }^{1}$ The term "mainland Ukraine" (Ukrainian: materykova Ukraina, Russian: materikovaâ Ukraina) is used in Ukraine to refer to the territory of the whole of Ukraine without the Crimean peninsula. 


\section{The Crimean Tatar Muslim IDPs in mainland Ukraine: The numbers and the reasons behind their migrations}

Determining the number of Crimean Tatars internally displaced persons (IDPs) from Crimea after the annexation is a difficult task. According to the report by the European Commission against Racism and Intolerance, affiliated with the Council of Europe, there are around 20,000 Crimean Tatars, as well as persons of other nationalities, who have fled Crimea. ${ }^{2}$ Based on approximations of the social workers dealing with IDPs, it is possible to assess that at least half of them are Crimean Tatars, so the number may be more or less 10,000 people. ${ }^{3}$ Other sources, however, point to a much higher number of internally displaced persons from the region, but it is impossible to establish exact figures as the majority of the IDPs did not officially register. ${ }^{4}$ Taking into account the number of Crimean Tatars in Ukraine $(248,000$, including Crimea, according to the last census, from 2001), it should be regarded as a significant, but still not that large, share of the Crimean Tatar population.

However, the number of IDPs is rising. According to Yusuf Kurkchi, First Deputy Minister on issues of temporarily occupied territories and internally displaced persons of Ukraine, annually about 2,000-3,000 local residents leave the Russian-occupied Crimea. ${ }^{5}$ In an interview in June 2018, an official from the Mission of the President of Ukraine in the Autonomous Republic of Crimea gave the number of 34,000 officially registered IDPs from Crimea in mainland Ukraine (not only Crimean Tatars, but also of other ethnicities). At the same time, he acknowledged that the real number, that is including unregistered IDPs, might be as high as 80,000 people. ${ }^{6}$ An activist of regional Mejlis ${ }^{7}$ in Kherson in the interview estimated the number of the Crimean Tatars in Kherson Oblast' at 11,000 to 12,000 people, mostly in Genichesk and Novooleksiyivka. As for neighbouring Zaporizhia Oblast, he claimed that there may be 3,500 - including 2,500 in the city of Melitopol. These numbers, however, include also those Crimean Tatars who lived in the region before 2014. Other major

${ }^{2}$ ECRI Report on Ukraine (Fifth Monitoring Cycle), Adopted on 20 June 2017, Published on 19 September 2017, https:/www.coe.int/t/dghl/monitoring/ecri/Country-by-country/Ukraine/UKR-CbC-V2017-038-ENG.pdf [access: 07.09.2018].

3 Krymskie pereselency v Kieve: “Hotelos' by nazad vernut'sâ,” (19.03.2017), https://ru.krymr. com/a/28378584.html [access: 07.09.2018].

${ }^{4}$ G. Uehling, A Hybrid Deportation: Internally Displaced from Crimea in Ukraine, [in:] Migration and the Ukraine Crisis. A Two-Country Perspective, A. Pikulicka-Wilczewska, G. Uehling (eds.), Bristol 2017, p. 63.

5 Annually about 2-3 Thousand People Leave Crimea - Kurkchi (4.06.2018), http://qha.com.ua/en/ society/annually-about-23-thousand-people-leave-crimea-kurkchi/143464/ [access: 07.09.2018].

6 The author's interview with official of the Mission of the President of Ukraine in the Autonomous Republic of Crimea in Kherson, conducted on 25.06.2018.

${ }^{7}$ Regional Mejlis in Kherson is a branch of the Mejlis of Crimean Tatar People, (Crimean Tatar: Qurımtatar Milliy Meclisi), which is the executive-representative body of the Kurultay of the Crimean Tatar People (Crimean Tatar: Qurımtatar Milliy Qurultayl), a national congress and the highest representative body. The Mejlis comprises the delegates elected by the Kurultay. The term of office of the Kurultay members is five years. 
communities of Crimean Tatar IDPs, according to him, are in L'viv $(1,500-2,000)$ and Kyiv (about 1,000). ${ }^{8}$

There are several reasons behind the Crimean Tatars' decisions to move from the occupied Crimea to mainland Ukraine, the main one being Russian authorities' persecution of this group. The repressed members of the Crimean Tatar community may be divided into two categories: those subjected to harassment due to their political activism and those who faced persecution because of their religious affiliation, i.e. members of the Salafi and other neo-fundamental Islamic groupings. In some cases, however, these two categories overlap.

The first of these groups consists of the social and political elite of the Crimean Tatars. In their case, they were mostly people representing pro-Ukrainian views during the Euromaidan Revolution and after the Russian annexation of Crimea. In 2014 the leaders of the Mejlis of the Crimean Tatar people (Crimean Tatar: Qirımtatar Milliy Meclisi) - both the former head of this organisation, Mustafa Dzhemilev and current head, Refat Chubarov - were not allowed to enter the peninsula's territory by occupational authorities and were banned from entering the territory of the Russian Federation for five years. ${ }^{9}$ Subsequently, the Mejlis was banned by Russian authorities in Crimea, and in April 2016 it was declared an extremist organisation, illegal on the territory of the Russian Federation. ${ }^{10}$ Influential members of the Mejlis were forced to leave the territory of Crimea under the threat of false criminal accusations and arrest. Those who stayed were subjected to repressions by the new authorities, Russia-appointed prosecutors, and the Russian Federal Security Service (FSB). One of the main politically motivated actions of the Russian prosecutor's office was the so-called 26 February case.

On 26 February 2014, during the Euromaidan Revolution in Kyiv, people protested in front of the building of the Supreme Council of the Autonomous Republic of Crimea in Simferopol. A pro-Russian group was organized by the Russian Unity party and a pro-Ukrainian one, supporting the territorial integrity of Ukraine, gathered by the Mejlis. In the course of the demonstrations, two people died and others sustained injuries. Later - after the annexation of the peninsula - in 2015 several members of the Mejlis, including Akhtem Chiygoz, were detained for participating in the 26 February rally. ${ }^{11}$ Another spectacular case of political persecution was the detention of Ilmi Umerov for his pro-Ukrainian comments on television. Both Chiygoz and Umerov were held in custody for a long time without trial (more than two

${ }^{8}$ The author's interview with activist of regional Mejlis in Kherson, conducted on 26.06.2018.

${ }^{9}$ Glavu Medžlisa Refata Čubarova ne pustili obratno v Krym (05.07.2015), https://ru.krymr. com/a/25446620.html [access: 07.09.2018].

${ }^{10}$ Obŝestvennoe ob'edinenie "medžlis krymskotatarskogo naroda" vklûčeno v perečen'obŝestvennyh ob'edinenij i religioznyh organizacij, dejatel'nost' kotoryh priostanovlena v svâzi s osû́estvleniem imi ekstremistskoj deatel'nosti (18.04.2016), http://minjust.ru/press/news/obshchestvennoe-obedineniemedzhlis-krymskotatarskogo-naroda-vklyucheno-v-perechen [access: 07.09.2018].

${ }^{11}$ Report of the International Expert Group. 26 February Case, Part 1. Reconstruction and legal analysis of the events of 26 February 2014 outside the building of the Supreme Council of the Autonomous Republic of Crimea in Simferopol, R. Martynovskyy, D. Svyrydova (eds.), Kyiv 2017, p. 67; https://helsinki.org.ua/wp-content/uploads/2018/02/201712_sajt_Press_Analit_ZvitA4_engl.pdf [access: 07.09.2018]. 
and a half years for Chiygoz, and one and half years for Umerov). Eventually, after being sentenced (Chiygoz for eight years of imprisonment, Umerov for two) they were released in October 2017 and sent to Turkey (they later came back to Ukraine). Reportedly, Turkish president Recep Tayyip Erdogan helped in negotiations with the Russian side on freeing Chiygoz and Umerov. ${ }^{12}$

The other mentioned group of Crimean Tatar Muslims persecuted by the occupational regime in Crimea are members of the neo-fundamental Islamic movements such Hizb ut-Tahrir or smaller Salafi communities. While it is difficult to assess the number of the members of these groups, and although they are definitely marginal groups within the whole population of the Crimean Tatar Muslims in Ukraine, it is quite clear that they constitute a large number of those Crimean Tatars who were forced to leave Crimea due to persecutions at the hands of the occupational regime.

\section{"Crimean Islam": The split within the Crimean Muslim community. The Crimean neo-fundamental Islamic groupings before and after the annexation}

Before explaining the circumstances of the exodus of the Muslims from the occupied peninsula, it is necessary to briefly present the history of Islamic communities on the peninsula after the collapse of the Soviet Union and the place of the neofundamental movements within this context. Since the early 1990s, the period of the return of Crimean Tatars to their historical homeland from the exile, the Mejlis has been trying to control the religious life of the whole Crimean Tatar community. The first mufti of the Spiritual Direction of the Muslims of Crimea (Crimean Tatar: Q irtm Musulmanları Diniy İdaresi, QMDİ, Ukrainian: Duhovne upravlinna musul'man Krimu, Russian: Duhovnoe upravlenie musul'man Kryma, DUMK, also called Crimean Muftiat) was Seitdzhelil Ibraimov. An ambitious person, the mufti had his sights on becoming leader of the whole Muslim community in Ukraine. However, among those Muslims living in mainland Ukraine, Crimean Tatars were a minority. Moreover, the Mejlis was interested in unification and synergy of the Crimean Tatar secular national movement with QMDİ, the dominant Islamic organization on the peninsula. Extending the authority of the Crimean mufti over all Ukrainian Muslims would have meant inclusion of non-Crimean Tatar believers and "internationalization" of the Spiritual Direction. As a result, Seitdzhelil Ibraimov resigned under pressure from the Mejlis. ${ }^{13}$ As the Ukrainian scholar O. Bohomolov asserts, the Mejlis' religious policy may be called ethno-Islamic as it tries to picture Islam as a part of Crimean Tatar national culture. ${ }^{14}$

${ }^{12}$ Crimean Tatar Leaders 'Freed,' Fly To Turkey (26.10.2017), https://www.rferl.org/a/ukrainecrimea-tatar-leaders-chiygoz-umerov-released/28815211.html [access: 07.09.2018].

${ }^{13}$ O.V. Bogomolov, S.I. Danilov, I.M. Semivolos, G.M. Âvorska, Islams 'ka identyčnist'v Ukraini, Kyiv 2005, p. 61.

${ }^{14}$ Ibidem. 
In Crimea, similarly, as in other post-Soviet regions inhabited by Muslims (Russia, Caucasus, Central Asia), the local version of Islam represented by the dominant structure (the muftiat) is called "traditional Islam." This notion is used in contrast to "radical Islam." The latter is often also called "Wahhabi Islam" in the post-Soviet space. The main feature of such neo-fundamental Islamic groupings is their rejection of all the pre-Islamic traditions and religious concepts developed after the death of Prophet Muhammad. The term for this current in Islam, accepted the by majority of its adherents, is Salafi Islam. ${ }^{15}$ The term points to the Arabic word "salaf," meaning ancestors or predecessors.

The governments of the post-Soviet states in the 1990s declared the adherents of the Salafi Islam, the Salafists, or the "Wahhabis," to be extremists and terrorists, and they initiated harsh policies against them. At the same time, they were claiming that these activities were only against false Islam, influenced by "foreign Islamic extremist centres." The majority of the governments, including Russia and Central Asian republics, also claim that they support "traditional Islam," that is the activities of legally registered spiritual administrations. ${ }^{16}$ The latter are also most often tolerant or supportive of the local Sufi practices and cults of holy places/graves of the holy men - elements of Islam strictly rejected by the Salafists. In the case of Crimean Muslims, the Crimean Sufi traditions were almost completely forgotten. The exception were the activities of Alife Yashlavska, who restored the old dervish tekkiye in Evpatoria and cultivated in her writings the memory of the Crimean Sufi practices. ${ }^{17}$ Regarding the memory of the holy places and the holy men's graves (Crimean Tatar: azizler), although it was restored in some places in Crimea after Crimean Tatars return to their homeland, it did not play a significant role in their religious life. ${ }^{18}$ The Sufi Islamic practices were also popularised in Ukraine, including Crimea, in recent decades by the Spiritual Administration of the Muslims of Ukraine (Ukrainian: Duhovne upravlinnâ musul'man Ukrainy, DUMU). This structure was founded in Kyiv by Ahmad Tamim, who received his Islamic education in Syria and Lebanon. Before going to Ukraine Mufti Tamim was a student of the Sufi religious leader Abd Allah al-Harari al-Habashi. Not surprisingly, the Spiritual Administration of the Muslims of Ukraine was closely connected ideologically and organizationally with the Sufi network structure Al-Ahbash. ${ }^{19}$ However, the QMDİ has always regarded the

${ }^{15}$ Salafi Islam is a broad term, but its adherents are divided into many various religious currents, often remaining in conflict with each other, like apolitical Salafis, jihadi Salafis, or factions like sururism or madkhalism. In post-Soviet countries the adherents of Salafi Islam often tend to call themselves simply followers of Islam and not to underline religious divisions. See I. Kaliszewska, Za Putina i za szarijat. Dagestańscy muzulmanie o Rosji i państwie islamskim, Warszawa 2016, pp. 112-116.

${ }^{16}$ G. Yemelianova, Islamic Radicalisation:A Post-Soviet, or a GlobalPhenomenon?, [in:] Radical Islam in the Former Soviet Union, G. Yemelianova (ed.), London-New York 2010, pp. 28-29.

${ }^{17}$ O.V.Bogomolov, S.I. Danilov, I.M. Semivolos, G.M. Âvorska, op. cit., p. 63.

${ }^{18}$ Ibidem.

${ }^{19}$ O. Yarosh, D. Brylov, Muslim Communities and Islamic Network Institutions in Ukraine: Contesting Authorities in Shaping of Islamic Localities, [in:] Muslims in Poland and Eastern Europe Widening the European Discourse on Islam, K. Górak-Sosnowska (ed.), Warszawa 2011, pp. 260-261. 
Tamim's muftiat as a competitive religious organisation. It also criticized its religious practices as "alien" to Crimean Islam.

The notion of traditional Crimean Islam is quite often used by Mejlis activists and ordinary Crimean Tatars. The memory of Ismail-bey Gasprinski (Gaspiral1), the Crimean Tatar nineteenth- and twentieth-century thinker, is also part of the collective picture of Crimean Islam shared by many Crimean Tatar Muslims. They are proud of the legacy of their compatriot, one of the most important reformers in the Turkic world and founder of the Jadidist movement in the Russian Empire. As the Jadid movement was merging Islam with the heritage of the European Enlightenment, the Crimean Tatars tend to view "their Islam" as more "enlightened" than, for instance, the Islam of Central Asia, which they were able to compare with their own version during the exile period after the 1944 Stalinist deportation. ${ }^{20}$

Nevertheless, towards the end of the 1990s the diversification and split within the Ukrainian Muslim community started to grow and also influence the situation on the Crimean peninsula. One of the first organizations established in Ukraine to compete with QMDİ Islamic was Ar-Raid, founded by the Ukrainian Arab community, mostly students or former students from the Middle East studying in Ukraine. In 1997 Ar-Raid was registered as an umbrella organisation unifying a number of Arab organisations in Kyiv, Kharkov, Odessa, Donetsk, Lugansk, Simferopol, Zaporizhia, Dnipropetrovsk, L'viv, and Vinnytsya. Ar-Raid quickly managed to gather believers of different ethnic origins. It had ideological and organizational links to the Federation of Islamic Organizations in Europe and its leader Yusuf Kardawi. ${ }^{21}$ In the early years of the twenty-first century, several Salafist organisations, including As Sunna, Birlik, and Zamzam, were established. These organisations were sometimes competing against, and sometimes collaborating with, Ar-Raid. ${ }^{22}$ Both the mentioned smaller Salafi communities as well as Ar-Raid were regarded by the majority of Crimean Tatars as "alien," "Arab" versions of Islam. Nevertheless, they have also managed to attract some members of the Crimean Tatar community.

Another neo-fundamental Islamic organisation, operating in Ukraine since the early 2000s, is Hizb ut-Tahrir. The Ukrainian authorities have taken an exceptionally tolerant stance regarding Hizb ut-Tahrir in the post-Soviet space. The organisation was illegal and harshly persecuted in almost all the post-Soviet states, especially in Central Asia, where it managed to find many supporters in the 1990s. However, in Ukraine it operated freely and even organised street protests in Crimea, for instance in 2003 against the U.S. invasion of Iraq. Conversely, in the Russian Federation since 2003 Hizb ut-Tahrir has been an illegal organisation and its members were persecuted. The reason behind such harsh treatment of this group in the postSoviet area is its neo-fundamental ideology. Hizb ut-Tahrir's goal is establishment of

${ }^{20}$ See the author's unpublished M.A. dissertation defended at the Institute of Ethnology and Cultural Anthropology of the University of Warsaw, based on his ethnographic fieldwork in Crimea in 20012002: K. Zasztowt, Tatarzy krymscy. Tożsamość narodowa i stereotypy etniczne, unpublished MA thesis at the Institute of Ethnology and Cultural Anthropology, University of Warsaw, 2003, pp. 52-53.

21 O.V. Bogomolov, S.I. Danilov, I.M. Semivolos, G.M. Âvorska, op. cit., pp. 34-35.

${ }^{22}$ Ibidem, p. 36. 
a global caliphate, but at the same time, the organisation rejects violence and terrorism as methods to reach this aim.

All of the above-mentioned Islamic groupings were criticized by the Mejlis. The Kurultay of the Crimean Tatar Nation (a national gathering of Mejlis delegates) emphasized in 2004 that it supports the Spiritual Direction of Crimean Muslims, the actions of which are based on "real values of Islam tolerance and good neighbourliness with all people." ${ }^{23}$ At the same moment Mustafa Dzhemilev was notifying that there were already thirty independent Islamic communities in Crimea (Hizb ut-Tahrir and the "Wahhabis") which were against QMDİ and causing tensions within the Muslim community of the peninsula. ${ }^{24}$ One conflict occurred when the Spiritual Direction forced the mufti of the historical Kebir Camii Mosque in Simferopol to step down. The mufti was a supporter of Hizb ut-Tahrir and openly criticized the Mejlis' leadership. $^{25}$

Although the Mejlis condemned Hizb ut-Tahrir, the Salafists and other neo-fundamental communities, the sociological research of Elmira Muratova of 2008 shows that Crimean Tatar Muslims were divided in their stance towards these organisations. Whereas $46 \%$ of the respondents claimed that "non-traditional" religious currents and organisations should not develop in Crimea, 33.3\% were saying that everyone has a right of choice and $13.5 \%$ shared the opinion that some selected elements of the "non-traditional" religious groups' activities may be accepted. ${ }^{26}$ The result, on the one hand, confirms to some extent the loyalty of the majority of the Crimean Tatars towards the QMDİ controlled by the Mejlis. On the other hand, it also shows a quite strong presence of other views. A significant number of the respondents rejected the idea that new Islamic communities should not develop in Crimea (and that the Crimean Tatars should be strictly confined to QMDI).

The quite significant group tolerant of, and moderately open to, "non-traditional" fundamental religious groupings may be explained by several various factors. Some of the young mullahs from these communities, educated in the Middle East, were regarded as representing a higher level of religious knowledge than the old mullahs, who were educated in the USSR and are usually associated with "traditional Crimean Islam." ${ }^{27}$ Some of the "non-traditional" Islamic organizations were also praised for their activities like teaching the believers Arabic. On the other hand, some Crimean Tatars sought an ideological alternative to the Mejlis and QMDİ. Many were disappointed with the activities of the secular national movement. The reasons behind this ranged from lack of success of the Mejlis in its fight for the rights of the Crimean Tatars (like land compensation to those who lost property due to the 1944 deportation, legal recognition of the Mejlis by the Ukrainian authorities, or education in their native language) to more general feelings of disappointment due to high levels

${ }^{23}$ M. Kirûşko, O. Boycova, Islam v Krymu, Kyïv 2005, p. 219.

${ }^{24}$ Ibidem.

25 Ibidem.

${ }^{26}$ E. Muratova, Krymskie musul'mane. Vzglâd iznutri. (Rezultaty sociologičeskogo isledovaniâ), Simferopol 2009, pp. 30-31.

${ }^{27}$ O.V. Bogomolov, S.I. Danilov, I.M. Semivolos, G.M. Yavorska, op. cit., pp. 25-26. 
of unemployment and poverty among the Crimean Tatars. At the same time, neofundamental religious organizations like Hizb ut-Tahrir promised social justice, and often provided some material support to its members. It does not come as a surprise that the Mejlis was gradually losing support, while other ideological/confessional options, including neo-fundamental Islam, were becoming increasingly attractive, especially for young Crimean Tatars.

The split in the Crimean Tatar Muslim community was growing before Russia's 2014 annexation of the peninsula. However, the political developments in Crimea under occupation changed the situation significantly. The goals of the occupational regime were to shape the religious life of Crimean Muslims in a mode similar to the Russian Federation. It was necessary for the Russian authorities to have a "muftiat" religious organisation which met two requirements. Firstly, it had to be completely submissive to Russia and accept the annexation. Secondly, it had to represent socalled traditional Islam. The problem was the political stance of QMDI. For years the Spiritual Direction of Crimean Muslims was loyal to the Mejlis. In the first phase of occupation, the Russian government offered possibility of collaboration to the secular leadership of the Crimean Tatars, to Mustafa Dzhemilev and Refat Chubarov. Dzhemilev had a telephone conversation with Russian president Vladimir Putin, but refused to collaborate with the Kremlin. Soon Emirali Ablayev, the head of QMDI, came to be pressured by the Russian authorities. In summer of 2014 the new alternative to QMDI, Taurida muftiat, was registered. Apparently establishment of the new structure was intended to show Mufti Ablayev that his Spiritual Direction could soon be replaced. ${ }^{28}$ Finally, after several months of silence, at the end of 2015 the head of QMDİ started to criticize the leaders of Mejlis (already banned from entering Crimea). Soon he became useful for the new authorities, when he urged them to fight the activities of the Hizb ut-Tahrir. ${ }^{29}$ His calls were followed by a wave of arrests of the members of the organisation. ${ }^{30}$ In reaction to Ablayev's switch of loyalty from Ukraine to Russia in January 2016, the Mejlis announced the establishment of a new, independent Crimean muftiat. ${ }^{31}$

Several of the Crimean Tatars arrested in the cases of the Hizb ut-Tahrir Yalta, Bakhchisaray, and Simferopol groups were once political and social activists. Their activism was the real reason for their arrests and persecution by the Russian authorities. A good example illustrating the Hizb ut-Tahrir legal cases in Crimea is the case of Emir Usein Kuku. After the annexation he became a member of the Crimean

${ }^{28} \mathrm{~K}$. Zasztowt, Instytucje religijne muzulmanów Ukrainy przed i po aneksji Krymu przez Federacje Rosyjska w 2014 roku, [in:] The World of Islam. Politics and Society, vol. 1: Politics, I. Kończak, M. Lewicka, A. Nalborczyk (eds.), Toruń 2017, pp. 75-76.

${ }^{29}$ Ibidem, p. 76.

${ }^{30}$ Since 2014 at least 19 people were arrested on suspicion of membership. Amnesty International: u Krymu vynyŝût' inakomyslennâ (15.12.2016), https://www.dw.com/uk/amnesty-international\%D1\%83-\%D0\%BA\%D1\%80\%D0\%B8\%D0\%BC\%D1\%83-\%D0\%B2\%D0\%B8\%D0\%BD\%D0\%B $8 \% \mathrm{D} 1 \% 89 \% \mathrm{D} 1 \% 83 \% \mathrm{D} 1 \% 8 \mathrm{E} \% \mathrm{D} 1 \% 82 \% \mathrm{D} 1 \% 8 \mathrm{C}-\% \mathrm{D} 1 \% 96 \% \mathrm{D} 0 \% \mathrm{BD} \% \mathrm{D} 0 \% \mathrm{~B} 0 \% \mathrm{D} 0 \% \mathrm{BA} \% \mathrm{D} 0 \% \mathrm{BE}-$ $\% \mathrm{D} 0 \% \mathrm{BC} \% \mathrm{D} 0 \% \mathrm{~B} 8 \% \mathrm{D} 1 \% 81 \% \mathrm{D} 0 \% \mathrm{BB} \% \mathrm{D} 0 \% \mathrm{~B} 5 \% \mathrm{D} 0 \% \mathrm{BD} \% \mathrm{D} 0 \% \mathrm{BD} \% \mathrm{D} 1 \% 8 \mathrm{~F} / \mathrm{a}-36770894$ [access: 12.09.2018].

${ }^{31}$ Koти nužen novyj muftiat? (06.01.2016), https://ru.krymr.com/a/27470367.html [access: 12.09.2018]. 
Contact Group on Human Rights, offering juridical help to the arrested Crimean Tatar activists and their families. Soon, in April 2015, he was arrested himself and beaten, but then released on the same day. After he ignored this "warning" of the Russian security apparatus, he was arrested again in February 2016 and accused of links to Hizb ut Tahrir. ${ }^{32}$ Later he was illegally transferred by the Russian authorities to Rostov-on-Don in Russia. According to Crimean lawyer and human rights' activist Emil Kurbeddinov, the case is absolutely politically motivated, but it may end with a verdict of 10 years to life in prison. ${ }^{33}$

Kurbeddinov himself was arrested in Crimea on 6 December 2018. Allegedly, according to Russian prosecutors, in 2013 he had posted symbols of Hizb ut-Tahrir on his Facebook account. Crimean human rights defenders claim that the whole accusation is based on false evidence. Kurbeddinov's arrest happened just after he declared his intention to defend members of the Ukrainian navy captured on the Black Sea after their vessels tried to cross the Kerch Strait from the Black Sea to the Sea of Azov on 25 November. For Crimean human rights activists it is evident that it was an attempt to intimidate all of the lawyers involved in political legal cases in Crimea. ${ }^{34}$

Interestingly, the attitude of Ukrainian security services toward Hizb ut-Tahrir has changed. Before the annexation it was negative, although the group was not delegalized or forbidden, it was still regarded as a threat by the security agency ${ }^{35}$ After the occupational authorities in Crimea started the political trials of members of the Hizb ut-Tahrir, the Ukrainian government began to treat them as almost "national heroes" and victims of the unjust Russian regime.

\section{The Crimean Tatars and the Ukrainian state}

However, the Mejlis of the Crimean Tatar people remains the main partner of the Ukrainian government within the Crimean Tatar Muslim community. The Mejlis leaders Dzhemilev and Chubarovhave been active in Ukrainian national politics since the early 1990s. Since the Soviet times the Crimean Tatar community has been united into one political movement, and since 1991 represented by the Mejlis, which has been involved in cooperation with various Ukrainian political groupings. Among the Mejlis' Ukrainian partners were centre-right, pro-European parties, often originating from anti-Communist opposition in the Soviet times. In the 1990s the Mejlis were allied with the People's Movement of Ukraine ("Rukh"). In 2004 the Mejlis supported

32 "Terroristy" bez teraktov: za čto sudât “âltynskuu sesterku” musul'man (07.02.2018), https:// ru.krymr.com/a/29025371.html [access: 12.09.2018].

${ }_{33}$ Podalše ot Kryma: počemu figurantov simferopol'skogo "dela Hizb ut-Tahrir" etapiruût $v$ Rossiu (29.08.2018), https://ru.krymr.com/a/pochemu-figurantov-dela-hizb-ut-tahrir-etapiruyut-v-rossi$\mathrm{yu} / 29459609 . \mathrm{html}$ [access: 12.09.2018].

${ }^{34}$ V Krymu zaderzan krymsko-tatarskij advokat Emil' Kurbedinov (6.12.2018), https://p.dw.com/ p/39ZeW [access: 12.12.2018].

${ }^{35} \mathrm{~K}$. Zasztowt, Instytucje religijne muzutmanów Ukrainy..., op. cit., p. 73. 
the Orange Revolution, and in subsequent years Victor Yushchenko's Our Ukraine Bloc and Yulia Tymoshenko's All-Ukrainian Union "Batkivshchina."

Dzhemilev and Chubarov have been elected members of the Ukrainian parliament, Verkhovna Rada, since 1998. They were both elected for the first time on the "Rukh" ticket. Then both were re-elected again in 2002, 2006, and 2007 representing Yushchenko's Our Ukraine Bloc. ${ }^{36}$ Yushchenko was also the first president of Ukraine to publicly mention the issue of the 1944 deportation, and he questioned the idealised picture of the Soviet victory in the Second World War. As he emphasized, for the Crimean Tatars the end of the war meant the beginning of totalitarian repressions. ${ }^{37}$

In the 2010 presidential election the Crimean Tatars openly supported Tymoshenko against pro-Russian candidate Victor Yanukovych. In 2012 Dzhemilev was elected a member of parliament as a candidate of her party, "Batkivshchina." ${ }^{38}$ That also coincided with worsening of the situation of the Crimean Tatar minority during the Yanukovych presidency and the rule of the Party of Regions. During the Euromaidan and the Russian military intervention in Crimea, the Crimean Tatars were the most vocal group protesting against Yanukovych, and subsequently Russia's annexation of the peninsula. Since then the Mejlis has been in alliance with the 2014 Petro Poroshenko's Bloc "Solidarnist." Dzhemilev and Chubarov were once again elected as members of the parliament in October 2014, as members of Poroshenko's Bloc.

The post-Euromaidan Ukrainian government appreciated the role of the Crimean Tatar community in resistance against Russian occupation of the peninsula. For instance, on 17 March 2014, the Ukrainian parliament issued a law guaranteeing the rights of the Crimean Tatars and legally recognized the Mejlis as the Crimean Tatars highest representative body. (The Crimean Tatar community had been waiting for this legal move since the early 1990s). Then, on 16 May 2014 president Petro Poroshenko issued a decree establishing the Day of Struggle for the Rights of the Crimean Tatar People. Later, on 12 November 2015, the parliament of Ukraine recognized the Stalinist deportation of Crimean Tatars in 1944 as genocide and proclaimed 18 May as the Day of Remembrance for the Victims of Genocide of the Crimean Tatar People. ${ }^{39}$

However, the relationship between the Mejlis' leaders and their Ukrainian political allies, namely Poroshenko's Bloc, although close, has not developed without problems. The Mejlis is still waiting for the politically most important decision of Ukraine, which is recognition of Crimea as "Crimean Tatar national autonomy." On 16 May 2018, two days before the anniversary of the deportation, a radical Crimean Tatar politician, Lenur Islamov, warned Ukrainian authorities that the Crimean Tatar community was ready to protest unless the Crimean Tatar autonomy in Crimea was

36 S. Stewart, Explaining the Low Intensity of Ethnopolitical Conflict in Ukraine, Münster 2005, p. 194.

37 A. Portnov, Istorii dlâ domasn'ogo vzytku. Esei pro pols'ko-rosijs'ko-ukrains'kij trykutnik pam'ati, Kyiv 2013, p. 180.

38 Povnyj spisok kandydativ u narodni deputaty vid VO “Bat'kivŝina” (30.07.2012), https://www. pravda.com.ua/articles/2012/07/30/6969797/ [access: 07.09.2018].

39 Ukraine Honors Victims of Genocide against Crimean Tatar People (18.05.2018), https://www. ukrinform.net/rubric-society/2462918-ukraine-honors-victims-of-genocide-against-crimean-tatar-people.html [access: 07.09.2018]. 
enshrined in the Ukrainian constitution. ${ }^{40}$ On the day of the anniversary, however, Poroshenko declared that "in the near future the parliamentary working group will finish work on amendments to the constitution regarding the status of the Crimean Tatar autonomy and will send the results to the constitutional commission." ${ }^{41}$ Although the president supported constitutional changes reflecting Crimean Tatar postulates, he added that he has "no illusions that the discussion will be easy." 42

Obviously, the establishment of any autonomy within the unitary system of Ukraine is a matter of grave concern for the Ukrainian political elite and society in general, considering the Russia-sponsored separatist activity in Donbas, and other potentially separatist movements in the Zakarpattia region (the Hungarians and the Rusyns) ${ }^{43}$ The federalization of Ukraine, which has been postulated by Russia and pro-Russian separatists since the so-called Minsk Protocol signed in September 2014 is perceived by many in Ukraine as a veiled term, in reality meaning further strengthening of separatism and weakening of central authorities in Kyiv. ${ }^{44}$

Taking into account this geopolitical context, it is no surprise that since spring 2016 Russian internet media have been spreading disinformation about allegedly planned Crimean Tatar autonomy in Ukraine's Kherson Oblast. The concept of establishing such an autonomy in the region neighbouring Crimea was indeed discussed and lobbied for some time by the Mejlis leadership. ${ }^{45}$ However, Russian provocative articles on the internet added false information to the story, such as insinuations that control of the region would be given to Turkey. ${ }^{46}$ The ultimate goal of the Russian media propaganda campaign was to trigger anger among the local Slavic population in Kherson Oblast. Whereas any prospects of de-occupation of Crimea are vague and attract little interest in Ukraine, the issue of granting special status or autonomy to the Crimean Tatars in Kherson Oblast could have indeed prompted discontent of not only non-Crimean Tatar inhabitants of the region, but the Ukrainian public in general.

40 “Ves' narod ždet”: vlastâm Ukrainy postavili ul'timatum po Krymu (16.05.2018), https://www. obozrevatel.com/politics/ves-narod-zhdet-vlastyam-ukrainyi-postavili-ultimatum-po-kryimu.htm [access: 07.09.2018].

${ }^{41}$ Porosenko: Izmenenia v Konstituciu po krymskotatarskoj avtonomii usilat suverenitet Ukrainy (18.05.2018), https://ru.krymr.com/a/news/29235918.html [access: 07.09.2018].

${ }^{42}$ Ibidem.

${ }^{43}$ R. Bari Urcosta, Controversies Over Proposed Crimean Tatar Autonomy in Ukraine, "Eurasia Daily Monitor," vol. 14, no. 72, https://jamestown.org/program/controversies-proposed-crimean-tatarautonomy-ukraine/ [access: 07.09.2018].

${ }^{44}$ A. Motyl, Why Russia Wants the Federalization of Ukraine (28.08.2014), https://www.huffingtonpost.com/alexander-motyl/russia-ukraine-federalization_b_5727256.html [access: 07.09.2018].

${ }^{45}$ Email correspondence with a member of the Mejlis, August 2018.

${ }^{46}$ For example of Russian propagandist internet article about Crimean Tatar autonomy in Kherson see: Poroshenko gives Kherson region to Turks (7.04.2016), http://www.pravdareport.com/news/world/ ussr/ukraine/07-04-2016/134097-kherson-0/ [access: 07.09.2018]. 


\section{History and present situation of the Crimean Tatar Muslims in Kherson and Zaporizhia Oblasts}

Kherson Oblast, which borders the occupied peninsula, is home to 10,000 to 12,000 Crimean Tatars, both IDPs and people living in the region since the Soviet times. Among the 60,000 inhabitants of Genichesk District about 8,000 are Crimean Tatars. ${ }^{47}$ Apart from Genichesk, the capital of the district, the biggest group of Crimean Tatars live in the nearby town of Novooleksiivka, according to Ukrainian categorization called urban-type settlement (Ukrainian: selise mis 'koho typu). There are more than 10,000 people living in the town, with significant representation of Crimean Tatars. A visible sign of the presence of Crimean Tatar Muslims in Novooleksiivka is their mosque - Dzhuma Dzhami "Adzhi Belal," named after local Muslim community leader, Adzhi Belal-efendi. Genichesk District after 2014 indeed became a centre of Crimean Tatar social and political activity.

The region adjacent to the Crimean Peninsula has been inhabited by Crimean Tatars since the late 1950s. Moreover, the whole northern Black Sea basin steppe zone has deep historical links to the Crimean Tatars' statehood - the Crimean Khanate. The borders of this Genghisid state, existing from the 1440s until the annexation by the Russian Empire in 1783, extended from the western part of the North Caucasus (Circassian-Kabardian vassal principalities) in the east to Budjak/Bessarabia on the northwest of the Black Sea coast. From 1475 the khanate was itself a vassal of the Ottoman Empire, nevertheless it retained a high degree of autonomy and continued to exert control over the tribes outside the Crimean peninsula. These included Circassian/Adighe tribes of the western part of the Northern Caucasus and several Turkic nomad Nogay tribes residing in the steppe zone of northern Black Sea region.

The nomads were divided into so-called ordas (the "hordes," or the "armies"). The Nogays or Nogay Tatars used to live in the steppe territory between the Azov Sea and Astrakhan Khanate on the northern shore of the Caspian Sea. However, after Muscovy's conquest of this khanate in 1556 many Nogays migrated to the west. There they became vassals of the Crimean khans and split into several tribal confederations. The ordas included the Kuban Nogays (at times loyal to Muscovy's tsars) living on the north of Azov Sea, Yedichkul Nogays inhabiting plains adjacent to the Crimean peninsula, Jamboyluk Nogays controlling the steppe westward from Crimea to the Bug River, Yedisan Nogays between the Bug and Dniester Rivers, and Budjak Nogays on the territory between the Dniester and the Danube Rivers. ${ }^{48}$ They were used by the Crimean khans in the military campaigns against the Northern neighbours - the Polish Lithuanian Commonwealth and Muscovy. Nevertheless, for the rulers the Nogays were an element of the khanate society which proved difficult to control. They quite often rebelled against the khans, or were used against the khanate by the Muscovites or the Ottomans. ${ }^{49}$

\footnotetext{
${ }^{47}$ The author's interview with activist of regional Mejlis in Kherson, conducted on 26.06.2018.

${ }^{48}$ A.W. Fisher, The Crimean Tatars, Stanford 1978, pp. 24-25.

${ }^{49}$ Ibidem, p. 25.
} 
The nomad Nogays also differed culturally and religiously from other subjects of the Crimean Khanate living within the territory of the peninsula, who mostly led a sedentary life. The Nogay tribes, however, considered their nomad way of life superior to the agricultural or urban, sedentary way of life of inhabitants of the peninsula. ${ }^{50}$ They also belonged to another juridical madhab within Sunni Islam: whereas the Crimeans were mostly followers of Hanafi juridical school, the Nogays, who were generally loosely attached to Islamic tenets of faith and did not possess any mosques or mullahs, nominally were adherents of the Shafi'i madhab. According to Ottoman explorer Evliya Çelebi's account, Seyahatname, the reason behind this choice was the lack of an alimentary prohibition related to horse meat, which existed in the Hanafi school. ${ }^{51}$ Nevertheless, the Nogays were influencing the life of sedentary Crimeans, first of all through trade. One of the significant element of this trade was the slave trade, in which both sides were deeply engaged, including the Christian part of the peninsula's population. ${ }^{52}$

The areas adjacent to the Crimean peninsula, more or less overlapping with contemporary Ukraine's Zaporizhia and Kherson oblasts, were called by the Ukrainians and the Poles the Wild Fields (Ukrainian: Dike Pole, Polish: Dzikie Pola), and they formed the borderland where the Ukrainian Cossacks had fought numerous battles against the Nogays and the Crimean Tatars. However, both groups - Christian Cossacks and Crimean Khanates' Muslims - also quite often entered alliances. The most important precedent was the support given by the Crimean Khan Islam Girey to the Cossack Hetman Bohdan Khmelnytsky during his uprising against the Polish-Lithuanian Commonwealth in 1648. The concept of a Cossack-Crimean political and military alliance was still vivid at the turn of the seventeenth and eighteenth centuries. One Zaporizhian leader who entered such a coalition in the 1690s was Hetman Petro "Petryk" Ivanenko. In the opinion of Ukrainian historians, this was a very important strategic change as it ended the period of the Zaporizhian Cossacks' alliance with Tsars of Muscovy since the Pereyeslav Treaty of $1654 .{ }^{53}$ Another important period of Cossack-Crimean cooperation in the early decades of the eighteenth century was establishment of the so-called Khan's Ukraine, the Cossack autonomy between the Dnipro and Dnister Rivers with the centre in Oleshkivska Sich, formally under authority of the Crimean Khan. The Crimean Tatars and Zaporizhian Cossacks' alliance also included trade relations, especially the export of salt from salt lakes on the coasts of the Black and Azov Seas. ${ }^{54}$

The Nogays remained in the northern Black Sea steppes even after the annexation of the region by the Russian Empire. Paradoxically, the policies of Russian Empress Catherine II led to immigration of some Nogay tribes from the North Caucasus and Bessarabia to regions adjacent to the Crimean Peninsula. The Nogays were the first

${ }^{50}$ Ibidem, p. 24.

${ }^{51}$ M. Kirûşko, O. Boycova, op. cit., p. 94.

${ }^{52}$ A.W. Fisher, op. cit., p. 26. See also: D. Quirini-Popławska, Włoski handel czarnomorskimi niewolnikami w późnym średniowieczu, Kraków 2002.

53 V. Serhiycuk, Ukrains 'kyj Krym, Kyiv 2001, p. 26.

${ }^{54}$ V.E. Vozgrin, Istoriceskie sud'by krymskih tatar, Moskva 1992, p. 237. 
colonizers of the territories of Melitopol County. The town of Melitopol was established on the site of the former Nogay aul (village) of Kyz-yar. In 1796 the Russian government granted to the Nogay tribes territories in Taurida Governorate between the Molochna and Berda Rivers. ${ }^{55}$ There in 1821 the town of Nogaisk was established on the Azov Sea coast. ${ }^{56}$ In the first half of nineteenth century - with developing colonization of the steppe by Ukrainians, Russians, Germans, Jews, and others - the Nogay Tatars remained part of this multi-ethnic population. They often entered into trade exchange with their neighbours, including German Mennonites, who were the main group in Melitopol County. ${ }^{57}$

The reasons behind emigration of the Nogays from Taurida Governorate are not clear. Generally, in case of the Crimean Tatars, the main cause of their mass emigration to the Ottoman Empire in the nineteenth century was the Tsarist policy of seizing the land of Muslim peasants by Russian landowners. There were other reasons, such as religious discrimination by the Russian government and Ottoman emissaries' propaganda vowing the Crimean Muslims to leave Dar al-Harb, the territory ruled by the infidels, and move to the Ottoman Empire. The peak of emigration came in 1860-1862, when more than 50,000 Nogays left Taurida Governorate. In 1864 not a single Nogay remained in Melitopol county, only 16 in Berdiansk county and 22 in Dnieper county. ${ }^{58}$ Although the history of the Nogays in the Northern Black Sea region ended with their exodus to the Ottoman Empire, some Muslims continued to live in the region's towns. For instance, in 1904 Muslims (Turks and Tatars) constituted $3 \%$ of Melitopol's population. ${ }^{59}$

In the Soviet period both Zaporizhia Oblast and Kherson Oblast were industrialized regions where some representatives of nationalities traditionally professing Islam settled. These were, however, predominantly the Volga Tatars and Azerbaijanis. According to the 2001 Ukrainian national census, the biggest "Muslim" nationalities in both oblasts were the Volga Tatars (5,400 in Kherson Oblast; 5,100 in Zaporizhia Oblast). ${ }^{60}$ In Kherson Oblast the second "Muslim nationality" were the Turks $(3,700){ }^{61}$ It is not clear, however, whether the Turks were mostly immigrants from Turkey or Meskhetian Turks, who had migrated to Ukraine from Central Asia. ${ }^{62}$ In Zaporizhia Oblast the second "Muslim nationality" were Azerbaijanis $(2,400)$. The

${ }^{55}$ G. Bekirova, Krymskie tatary Melitopola: Istoria i sovremennost', [in:] $S$ toskoj po rodine... Sud'by krymskih tatar na Melitopolščine, G. Bekirova, M. Idrisova (eds.), Simferopol 2011, pp. 11-12.

${ }^{56}$ In 1964 Nogaisk was renamed into Prymorske, later as Prymorsk.

${ }^{57}$ R.K. Loewen, Family, Church and the Market. A Mennonite Community in the Old and the New Worlds, 1850-1930, Urbana-Chicago 1993, p. 14.

${ }^{58}$ G. Bekirova, op. cit., p. 12.

${ }^{59}$ Ibidem, p. 13.

${ }^{60}$ Raspredelenie naseleniâ po nacional'nosti i rodnomu âzyku. Zaporozskâ̂ oblast', http://2001. ukrcensus.gov.ua/rus/regions/select_reg5/?botton $=$ cens_db\&box $=5.1 \mathrm{~W} \& \mathrm{k} \_\mathrm{t}=23 \& \mathrm{p}=0 \& \mathrm{rz}=1$ _ $1 \& \mathrm{rz}$ b=2_1\%20\%20\%20\%20\%20\%20\%20\%20\%20\%20\%20\&n_page=1 [access: 14.02 .2019 ].

${ }^{61}$ Čislennost' $i$ sostav naseleniâ Hersonskoj oblasti po itogam Vseukrainskoj perepisi naseleniâ 2001 goda, http://2001.ukrcensus.gov.ua/rus/results/general/nationality/kherson/ [access: 14 02.2019].

${ }^{62}$ The Meshketian Turks originally lived in the Southern Caucasus. On 14 November 1944 the whole group was deported to Central Asia from the Georgian Soviet Socialist Republic. After the pogroms in Uzbekistan's Ferghana Valley in summer of 1989 around 90,000 Meskhetian Turks had to flee from the 
Crimean Tatars in Zaporizhia Oblast were a rather small minority (570 persons according to the 2001 national census) with the biggest community in Melitopol. ${ }^{63}$ In Kherson Oblast, according to the last Ukrainian census from 2001, the Crimean Tatars were the third "Muslim nationality" constituting $0.2 \%$ of the region's population $(2,100) \cdot{ }^{64}$

The majority of the Crimean Tatars in Kherson and Zaporizhia Oblasts were families of those deported by Stalin's regime in May 1944 from Crimea to Central Asia. Despite the Soviet ban against them returning to their historical homeland, they tried to do this from the 1950s until the 1980s. Many of them tried to settle in Crimea proper, but were expelled out of the administrative boundary and stayed in neighbouring Kherson Oblast. The others, aware of Soviet persecution of Crimean Tatars returning to Crimea, decided to settle in the vicinity of their historical homeland, assuming that it was better than remaining in exile in Central Asia. Another region adjacent to Crimea inhabited by Crimean Tatars was the Krasnodar Krai, then part of the Russian Soviet Federative Socialist Republic. In Soviet Ukraine, in Kherson Oblast, the biggest centres of Crimean Tatar population became the towns of Genichesk and Novooleksiivka and a few villages in their area, as well as Melitopol in Zaporizhia Oblast.

In Kherson Oblast in the Soviet times Crimean Tatars were facing discrimination, but to a much lesser degree than those in Crimea. The local Soviet authorities were trying to discourage them from settling down in the region, creating obstacles to finding employment and registering as local residents. Still, it was possible to overcome these bureaucratic, discriminative barriers. In Crimea proper, however, no Crimean Tatar was allowed to settle and those trying to resist the ban were harshly punished and deported out of the peninsula. In result Kherson and Zaporizhia Oblasts in Soviet times became a kind of bridgehead for the Crimean Tatars striving to return to their historical homeland after the 1944 deportation. Many of them eventually moved to Crimea in the perestroika period in the 1980s and after the collapse of the Soviet system in the 1990s. Some of them remained in mainland Ukraine.

Somewhat similarly to how it was in the Soviet period, Kherson Oblast now has symbolic and political meaning for the Crimean Tatar national movement. The current political significance of this region is related to activities of the Ukrainian state and of the Crimean Tatar civil society. Due to the oblast's administrative border with the annexed peninsula, Ukraine decided to locate a Permanent Representative of the President in the Autonomous Republic of Crimea office in Kherson. During the first period after the annexation, the government in Kyiv was rather inactive regarding the issue of Crimea. The region was declared by Ukrainian parliament a "free trade zone" and the supplies of food products to the peninsula from mainland Ukraine were continued. The lack of political and economic governmental sanctions regarding the

region. Their destinations were mostly Azerbaijan and Russia. Some of them migrated to Ukraine. See T. Trier, G. Tarkhan-Mouravi, F. Kilimnik, Meskhetians: Homeward Bound, Tbilisi 2011, p. 27.

${ }^{63}$ Raspredelenie naseleniâ po nacional'nosti i rodnomu âzyku. Zaporozskâ̂ oblast', http://2001. ukrcensus.gov.ua/rus/regions/select_reg5/?botton=cens_db\&box $=5.1 \mathrm{~W} \& \mathrm{k} \_\mathrm{t}=23 \& \mathrm{p}=50 \& \mathrm{rz}=1$ _ $1 \& \mathrm{rz}$ b=2_1\%20\%20\%20\%20\%20\%20\% $20 \% 20 \% 20 \% 20 \% 20 \% 20 \% 20 \% 20 \& n \_$page=3 [access: 14.02 .2019$]$ ].

${ }^{64}$ Čislennost' $i$ sostav naseleniâ Hersonskoj oblasti po itogam Vseukrainskoj perepisi naseleniâ 2001 goda, http://2001.ukrcensus.gov.ua/rus/results/general/nationality/kherson/ [access: 14.02.2019]. 
breakaway region pushed the Crimean Tatar activists to initiate a blockade of the peninsula. The action was initiated in autumn 2015 as an act of civil disobedience by the Crimean Tatars together with Ukrainian nationalist, right-wing activists from the Right Sector. At the end of September 2015 they started to block transport of goods, mostly Ukrainian food products transported to Crimea, at the entry points to Crimean territory. The blockade was supported by the Mejlis of the Crimean Tatars and led by the activist Lenur Islamov. Later the Mejlis started to advocate not only the food embargo but also an energy embargo, the cutting of electricity supplies to annexed Crimea. Eventually, under pressure of the actions of the Crimean Tatars, the Ukrainian government agreed to the food embargo. As for the energy embargo, when the agreement on electricity transfer from mainland Ukraine to Crimea expired, it was not renewed after unsuccessful negotiations. In practice that meant introduction of an energy blockade. ${ }^{65}$

Several groups and organisations became involved in activities around the blockade, including the paramilitary organisation "Asker" and an unofficial, unregistered battalion named after Noman Çelebicihan; the non-government organisation Crimean Tatar Resource Center; and Crimean Tatar journalists (from TV ATR and Radio Meydan). "Asker" and the Çelebicihan battalion are civil society organisations with ambitions to achieve registration and status of official military unit from the government, as many Ukrainian dobrobats (voluntary battalions) have done since the launch of the war in Donbass in 2014. Nevertheless, they have not as yet received official registration. ${ }^{66}$

Even though the abovementioned political actions around the blockade did not have a significant impact on Russia's stance, they played a considerable role in terms of consolidation of the Crimean Tatars in mainland Ukraine, particularly in Kherson and Zaporizhia Oblasts. The local population, mostly Crimean Tatars, became involved in helping the activists at the blockade, bringing them food and other necessary items. The blockade point in Chonhar also started to attract teenage Crimean Tatar boys escaping from conscription into the Russian army in Crimea ${ }^{67}$ In a gesture of religious and political solidarity, some Chechen activists also participated in the blockade. In 2016 the Chechen Republic of Ichkeria's flag ${ }^{68}$ was raised at the base in Chonhar along with Ukrainian, Crimean Tatar, and the Çelebicihan batallion's flags (see pictures 1, 2, 3). The latter's emblems are interesting as they contain the Tatar symbols (shield with taraq tamga, emblem of the Girays' dynasty, and bow and arrows below), an inscription in the Latin Crimean Tatar alphabet (Crimean Tatar: vatan ya da ölüm, "homeland or death") as well as an Arabic inscription of sha-

${ }^{65}$ P. Kościński, K. Zasztowt, Ukraine’s Crimea Policy: A Strategy Deficit (4.11.2015), http://www. pism.pl/files/?id_plik=20821 [access: 30.11 .2018$]$.

${ }^{66}$ Muslim/Crimean Tatar voluntary military unit, which did achieve official registration in June 2014 as part of Ukraine's Interior Ministry's police formations was Battalion Krym (Crimea). The battalion consisted mostly, but not exclusively, of the Crimean Tatars and other Muslims. It was active in the antiterrorist operation in Donbass.

${ }^{67}$ The author's interview with the activists in Chonhar, conducted on 28.06.2017.

${ }^{68}$ The Chechen Republic of Ichkeria was an unrecognized secessionist government of the Chechen Republic in the 1990's. Since 2007 it has existed in exile in Great Britain. 


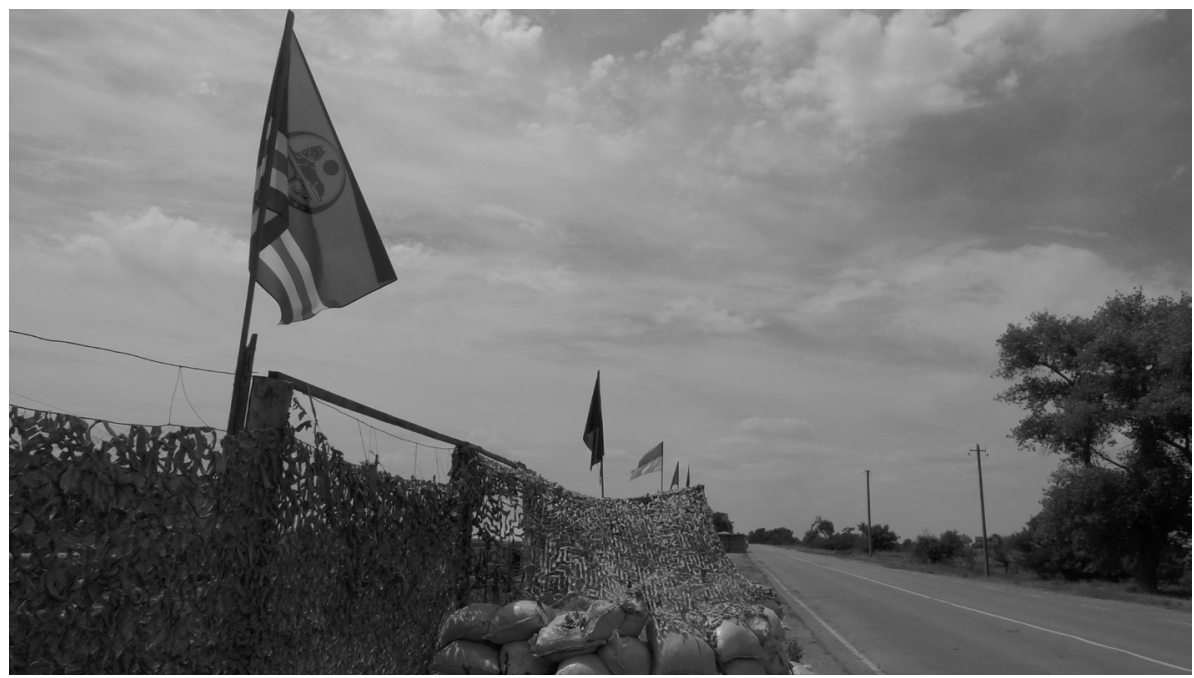

Picture 1. Flag of the Chechen Republic of Ichkeria at Chonhar, 28 June 2017, photo by Konrad Zasztowt

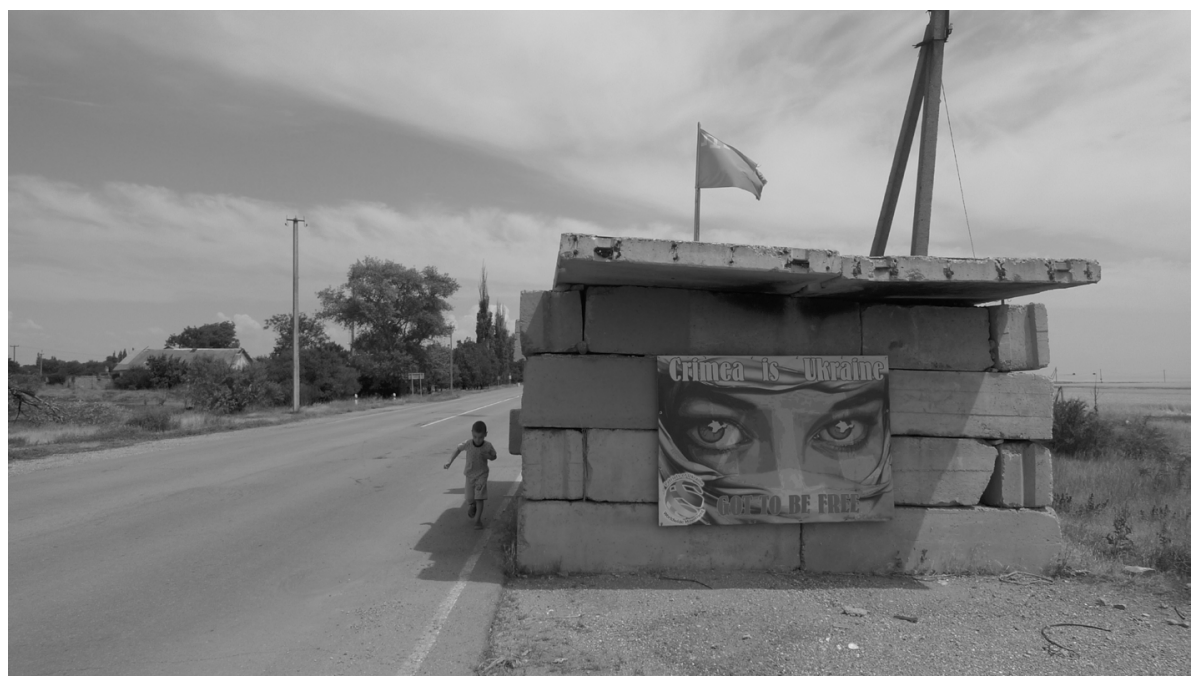

Picture 2. Crimean Tatar flag at Chonhar, 28 June 2017, photo by Konrad Zasztowt

hada (see picture 4). This inscription is similar to the one used on the Saudi Arabia flag (shahada on a green background) and even more resembles the flags of Hamas, Caucasus Emirate, or Front al-Nusra (shahada on a black background). Although the symbol of shahada itself is purely religious, its specific graphic style along with 


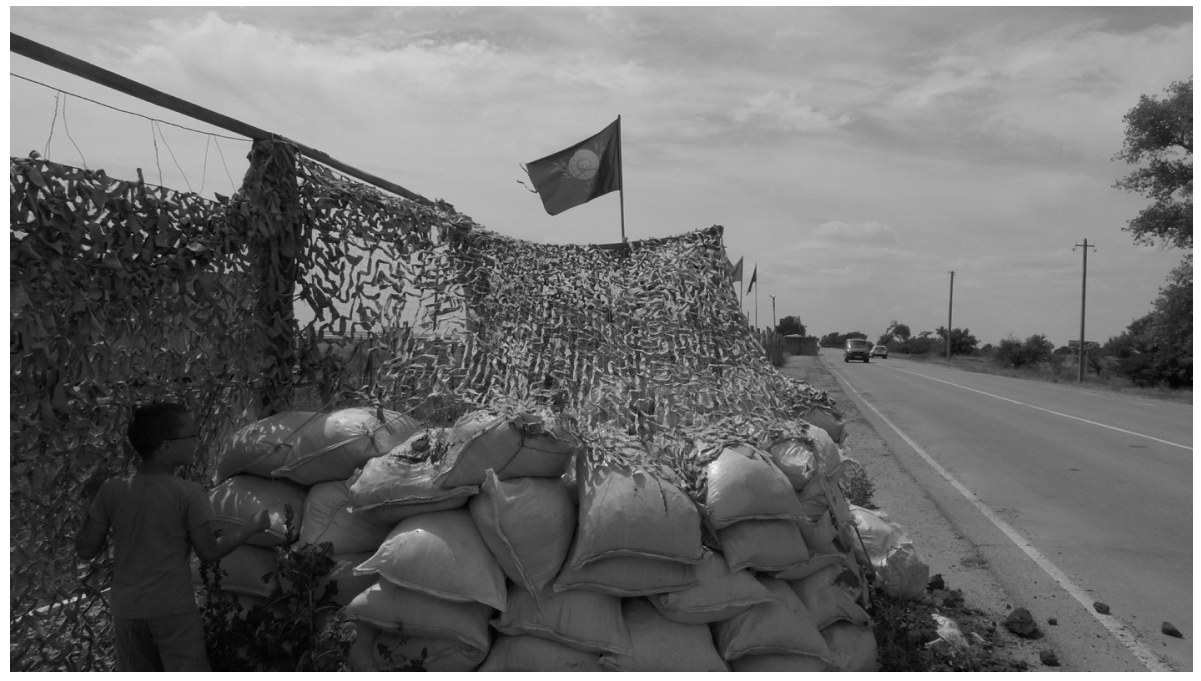

Picture 3. The Noman Çelebicihan Battalion's flag at Chonhar, 28 June 2017, photo by Konrad Zasztowt

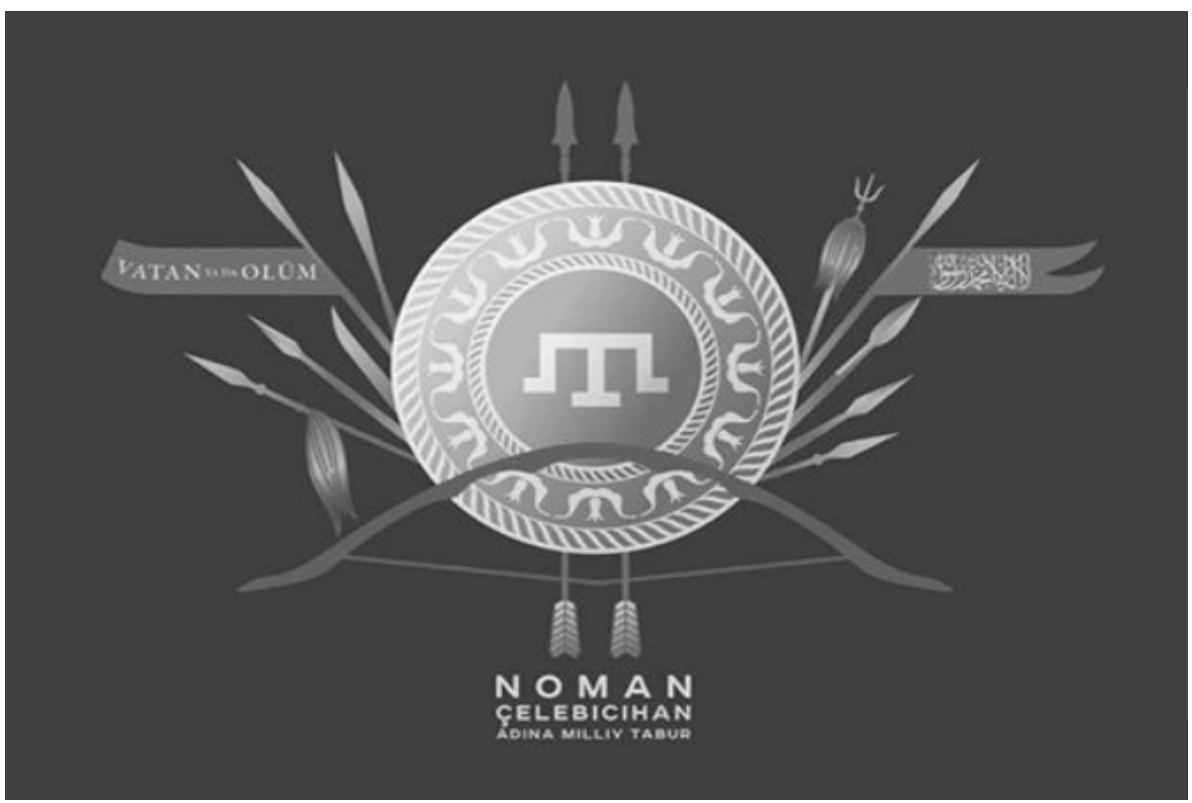

Picture 4. The Noman Çelebicihan Battalion's flag. Source: https://en.wikipedia.org/wiki/ Noman_\%C3\%87elebicihan_Battalion [access: 14.02.2019] 
the black background may suggest, especially to non-Muslims, that the Çelebicihan battalion has some affiliation to extremist or terrorist Islamic organisations. In fact, its ideology should be regarded first of all as nationalist or ethno-Islamic, and only additionally referring to Islamist or Pan-Islamist concepts. However, the Russian Kremlin-sponsored media did not hesitate to use the stereotypical association of Çelebicihan battalion's visual attributes and suggest that Crimean Tatar activists from the blockade are linked to extremist Islamic organisations from Syria. ${ }^{69}$

\section{Conclusions}

Russia's annexation of Crimea led to the exodus of quite a large group of Crimean Tatar Muslims from the peninsula, both political opponents of the occupational regime and members of the neo-fundamental groupings escaping the Russian state apparatus' oppression on religious grounds. These groups joined the Crimean Tatar population, which has lived in the Kherson and Zaporizhia Oblasts since the Soviet times. Some IDPs migrated also to the major cities of continental Ukraine, such as Kyiv or L'viv. The occupation of Crimea led to deeper fragmentation of the Crimean Tatar Muslim community. Already several years before 2014, the Crimean followers of Islam were divided into a majority of adherents of the Sunni Islam and Hanafi madhab represented by the QMDİ; some groupings loyal to the Spiritual Administration of the Muslims of Ukraine, propagating Sufism of Al Ahbash network; and the members of neo-fundamental minority groups like Hizb ut-Tahrir or Salafis. After the annexation of Crimea, the QMDİ was turned into a structure loyal to the Russian Federation. In response, the Mejlis of the Crimean Tatar People established another, independent Crimean muftiat, functioning outside of the peninsula. Paradoxically, the loss of Crimea influenced the interest of the Ukrainian state and society in the fate of Crimean Tatars, who are now regarded as the most loyal and pro-Ukrainian segment among the Crimean population. However, the main goal of the Mejlis, the Kyiv government's consent for creation of Crimean Tatar national autonomy, is still distant despite some promises from Ukrainian politicians. Since 2015 Kherson Oblast has played the most significant role for the Crimean Tatar activists trying to improve the political status of their community both in occupied Crimea and in mainland Ukraine. The administrative border with the peninsula has been a place of social and political activity of several Crimean Tatar organisations, including the above mentioned battalion named after Noman Çelebicihan involved in the blockade of Crimea. On one hand this activism led to strengthening of the Crimean Tatar Muslims' identity in the region. On the other hand, the Russian government and Russian-controlled media have started to paint these Crimean Tatar activities as "extremist," "Islamist," and "terrorist," and as even linked to jihadi organisations in Syria.

${ }^{69}$ See for instance: Komu prisâgaet "halifatčik" Porošenko? K čemu privedet nasazdenie islamistskoj "avtonomii" na rubežah Kryma? (7.10.2018), https://regnum.ru/news/2496057.html [access: 29.11.2018]. The article is illustrated with the flag with shahada. 


\section{References}

Amnesty International: u Krymu vynyŝût' inakomyslennâ (15.12.2016), https://www.dw.com/ uk/amnesty-international-\%D1\%83-\%D0\%BA\%D1\%80\%D0\%B8\%D0\%BC\%D1\%83\%D0\%B2\%D0\%B8\%D0\%BD\%D0\%B8\%D1\%89\%D1\%83\%D1\%8E\%D1\%82\%D1\%8C\%D1\%96\%D0\%BD\%D0\%B0\%D0\%BA\%D0\%BE\%D0\%BC\%D0\%B8\%D1\%81\%D0\%BB $\% \mathrm{D} 0 \% \mathrm{~B} 5 \% \mathrm{D} 0 \% \mathrm{BD} \% \mathrm{D} 0 \% \mathrm{BD} \% \mathrm{D} 1 \% 8 \mathrm{~F} / \mathrm{a}-36770894$ [access: 12.09 .2018 ].

Annually about 2-3 Thousand People Leave Crimea - Kurkchi (4.06.2018), http://qha.com.ua/en/ society/annually-about-23-thousand-people-leave-crimea-kurkchi/143464/ [access: 07.09.2018].

Bari Urcosta R., Controversies Over Proposed Crimean Tatar Autonomy in Ukraine, https://jamestown. org/program/controversies-proposed-crimean-tatar-autonomy-ukraine/ [access: 07.09.2018].

Bekirova G., Krymskie tatary Melitopolâ: Istoria i sovremennost', [in:] S toskoj po rodine ... Sud'by krymskih tatar na Melitopolščine, G. Bekirova, M. Idrisova (eds.), Simferopol 2011, pp. 9-24.

Bogomolov O.V., Danilov S.I., Semivolos I.M., Âvors'ka G.M., Islams 'ka identyčnist' v Ukraini, Kyiv 2005.

Čislennost' $i$ sostav naseleniâ Hersonskoj oblasti po itogam Vseukrainskoj perepisi naseleniâ 2001 goda, http://2001.ukrcensus.gov.ua/rus/results/general/nationality/kherson/ [access: 14.02.2019].

Crimean Tatar Leaders 'Freed,' Fly To Turkey (26.10.2017), https://www.rferl.org/a/ukrainecrimea-tatar-leaders-chiygoz-umerov-released/28815211.html [access: 07.09.2018].

ECRI Report on Ukraine Fifth Monitoring Cycle. Adopted on 20 June 2017, Published on 19 September 2017 (19.09.2017), https://www.coe.int/t/dghl/monitoring/ecri/Country-by-country/ Ukraine/UKR-CbC-V-2017-038-ENG.pdf [access: 07.09.2018].

Fisher A.W., The Crimean Tatars, Stanford 1978.

Glavu Medžlisa Refata Čubarova ne pustili obratno v Krym (05.07.2015), https://ru.krymr. com/a/25446620.html [access: 07.09.2018].

Kaliszewska I., Za Putina i za szarijat. Dagestańscy muzułmanie o Rosji i państwie islamskim, Warszawa 2016.

Kirûşko M., Boycova O., Islam v Krymu, Kyïv 2005.

Koти nužen novyj muftiat? (06.01.2016), https://ru.krymr.com/a/27470367.html [access: 12.09.2018].

Komu prisâgaet "halifatčik" Porošenko? K čemu privedet nasaždenie islamistskoj "avtonomii" na rubežah Kryma? (7.10.2018), https://regnum.ru/news/2496057.html [access: 29.11.2018].

Kościński P., Zasztowt K., Ukraine's Crimea Policy: A Strategy Deficit (4.11.2018), http://www. pism.pl/files/?id_plik=20821 [access: 30.11.2018].

Krymskie pereselency v Kieve: "Hotelos' by nazad vernut'sâ," (19.03.2017), https://ru.krymr. com/a/28378584.html [access: 07.09.2018].

Loewen R.K., Family, Church and the Market. A Mennonite Community in the Old and the New Worlds, 1850-1930, Urbana-Chicago 1993.

Motyl A., Why Russia Wants the Federalization of Ukraine (28.08.2014), https:/www.huffingtonpost. com/alexander-motyl/russia-ukraine-federalization_b 5727256.html [access: 07.09.2018].

Muratova E., Krymskie musul'mane. Vzglâd iznutri. (Rezultaty sociologičeskogo isledovaniâ), Simferopol 2009.

Obŝestvennoe ob'edinenie «medžlis krymskotatarskogo naroda» vklûčeno v perečen" obŝestvennyh ob'edinenij $i$ religioznyh organizacij, dejatel'nost' kotoryh priostanovlena $v$ svâzi s osusestvleniem imi ekstremistskoj deâtel'nosti (18.04.2016), http://minjust.ru/press/news/ obshchestvennoe-obedinenie-medzhlis-krymskotatarskogo-naroda-vklyucheno-v-perechen [access: 07.09.2018]. 
Podalše ot Kryma: počemu figurantov simferopol'skogo "dela Hizb ut-Tahrir" etapiruut v Rossiu (29.08.2018), https://ru.krymr.com/a/pochemu-figurantov-dela-hizb-ut-tahrir-etapiruyut-vrossiyu/29459609.html [access: 12.09.2018].

Poroshenko gives Kherson region to Turks (7.04.2016), http://www.pravdareport.com/news/world/ ussr/ukraine/07-04-2016/134097-kherson-0/ [access: 07.09.2018].

Porošenko: Izmenenia v Konstituciu po krymskotatarskoj avtonomii usilât suverenitet Ukrainy (18.05.2018), https://ru.krymr.com/a/news/29235918.html [access: 07.09.2018].

Portnov A., Istorii dlâ domaŝn'ogo vžytku. Esei pro pols 'ko-rosijs 'ko-ukrains 'kij trykutnik pam 'ati, Kyiv 2013.

Povnyj spisok kandydativ u narodni deputaty vid VO “Bat'kivŝina," (30.07.2012), https://www. pravda.com.ua/articles/2012/07/30/6969797/ [access: 07.09.2018].

Quirini-Popławska D., Włoski handel czarnomorskimi niewolnikami w późnym średniowieczu, Kraków 2002.

Raspredelenie naseleniâ po nacional'nosti i rodnomu âzyku. Zaporozskâ̂ oblast', http://2001. ukrcensus.gov.ua/rus/regions/select_reg $5 /$ ?botton $=$ cens_db\&box $=5.1 \mathrm{~W} \& \mathrm{k}$ $\mathrm{t}=23 \& \mathrm{p}=0 \& \mathrm{rz}=1 \_1 \& \mathrm{rz} \_\mathrm{b}=2 \_1 \% 20 \% 20 \% 20 \% 20 \% 20 \% 20 \% 20 \% 20 \% 20 \% 20 \% 20 \& \mathrm{n} \_$page $=1$ [access: 14.02.2019].

Report of the International Expert Group. 26 February Case, Part 1. Reconstruction and legal analysis of the events of 26 February 2014 outside the building of the Supreme Council of the Autonomous Republic of Crimea in Simferopol, https://helsinki.org.ua/wp-content/uploads/2018/02/201712_sajt_Press_Analit_ZvitA4_engl.pdf [access: 07.09.2018].

Serhiyčuk V., Ukrains 'kyj Krym, Kyiv 2001.

Stewart S., Explaining the Low Intensity of Ethnopolitical Conflict in Ukraine, Münster 2005.

"Terroristy" bez teraktov: za čto sudât "âltynskuu šesterku” musul'man (07.02.2018), https:// ru.krymr.com/a/29025371.html [access: 12.09.2018].

Trier T., Tarkhan-Mouravi G., Kilimnik F., Meskhetians: Homeward Bound, Tbilisi 2011.

Uehling G., A Hybrid Deportation: Internally Displaced from Crimea in Ukraine, [in:] Migration and the Ukraine Crisis. A Two-Country Perspective, A. Pikulicka-Wilczewska, G. Uehling (eds.), Bristol 2017, pp. 62-77.

Ukraine Honors Victims of Genocide Against Crimean Tatar People (18.05.2018), https://www. ukrinform.net/rubric-society/2462918-ukraine-honors-victims-of-genocide-against-crimeantatar-people.html [access: 07.09.2018].

“Ves' narod ždet”: vlastâm Ukrainy postavili ul'timatum po Krymu (16.05.2018), https://www. obozrevatel.com/politics/ves-narod-zhdet-vlastyam-ukrainyi-postavili-ultimatum-po-kryimu. htm [access: 07.09.2018].

V Krymu zaderžan krymsko-tatarskij advokat Emil' Kurbedinov (6.12.2018), https://p.dw.com/ p/39ZeW [access: 12.12.2018].

Vozgrin V.E., Istoričeskie sud'by krymskih tatar, Moskva 1992.

Yarosh O., Brylov D., Muslim Communities and Islamic Network Institutions in Ukraine: Contesting Authorities in Shaping of Islamic Localities, [in:] Muslims in Poland and Eastern Europe Widening the European Discourse on Islam, K. Górak-Sosnowska (ed.), Warszawa 2011, pp. 252-265.

Yemelianova G., Islamic Radicalisation: A Post-Soviet, or a Global Phenomenon?, [in:] Radical Islam in the Former Soviet Union, G. Yemelianova (ed.), London-New York 2010, pp. 11-30.

Zasztowt K., Instytucje religijne muzulmanów Ukrainy przed i po aneksji Krymu przez Federacje Rosyjska w 2014 roku, [in:] The World of Islam. Politics and Society, vol. 1: Politics, I. Kończak, M. Lewicka, A. Nalborczyk (eds.), Toruń 2017, pp. 65-78.

Zasztowt K., Tatarzy krymscy. Tożsamość narodowa i stereotypy etniczne, unpublished MA thesis at the Institute of Ethnology and Cultural Anthropology, University of Warsaw [2003]. 
Interviews quoted in the article conducted by Konrad Zasztowt during his study trips to Ukraine (June 2017, June 2018):

Interview with the activists in Chonhar, 28.06.2017.

Interview with activist of regional Mejlis in Kherson, 26.06.2018.

Interview with official of the Mission of the President of Ukraine in the Autonomous Republic of

Crimea in Kherson, 25.06.2018. 